DOI: https://doi.org/10.24127/ajpm.v10i4.4346

\title{
PENGARUH MODEL PEMBELAJARAN BLENDED LEARNING TERHADAP KEMAMPUAN BERPIKIR KRITIS MATEMATIKA PESERTA DIDIK SEKOLAH DASAR
}

\author{
Muncarno $^{1 *}$, Nelly Astuti ${ }^{2}$ \\ ${ }^{1 *, 2}$ Universitas Lampung, Bandar Lampung, Indonesia \\ *Corresponding author. \\ E-mail: $\quad \frac{\text { muncarno.muncar@gmail.com }}{{ }^{2 *} \text { nelly.astuti@fkip.unila.ac.id }}{ }^{2)}$
}

Received 21 October 2021; Received in revised form 04 December 2021; Accepted 28 December 2021

\begin{abstract}
Abstrak
Masalah dalam penelitian ini adalah rendahnya kemampuan berpikir kritis matematika peserta didik kelas $\mathrm{V}$ SD Negeri 1 Metro Barat. Berdasarkan masalah tersebut, penelitian ini bertujuan untuk mengetahui pengaruh yang signifikan pada model blended learning terhadap kemampuan berpikir kritis matematika. Jenis penelitian ini yaitu eksperimen semu dengan desain non-equivalent control group design. Sumbej dari penelitian ini adalah peserta didik kelas V di SD Negeri 1 Metro Barat, Lampung. Populasi berjumlah 36 orang peserta didi. Penelitian ini menggunakan teknik sampel jenuh berjumlah 36 peserta didik. Instrumen yang digunakan soal tes uraian mata pelajaran matematika. Analisis data menggunakan uji regresi sederhana dan rata-rata nilai $n$ gain. Hasil analisis data menunjukkan terdapat pengaruh yang signifikan dari penerapan model blended learning terhadap kemampuan berpikir kritis matematika peserta didik kelas V SD Negeri 1 Metro Barat. Disamping itu, terdapat peningkatan kemampuan berpikir kritis peserta didik sebesar 0,51 dengan kategori "Sedang". Hal ini menunjukkan bahwa model blended learning cocok untuk digunakan meningkatkan kemampuan berpikir kritis bagi peserta didik sekolah dasar khususnya kelas $\mathrm{V}$.
\end{abstract}

Kata kunci: Blended learning; kemampuan berpikir kritis; matematika.

\begin{abstract}
The problem in this research is the low critical thinking skills of students on grade V students elementary scholl 1 West Metro. The purpose of this trsearch is to determine the significant effect on the application of the blended learning models to the critical thinking skills mathematic. This type of research is quasi experimental research with the design used is non-equivalent control group design. The subject of this research are students in fifth grade of SDN 1 West Metro, Lampung. The study population was 36 students and use the sample was saturated. The instrument used was the mathematics subject description test questions. Data analysis techniques using a simple regression test. The result of this research said that blended learning can be used in mathematics learning especially in fifth grade effectively. Beside that, this research also conclude that the average of n-gain score are 0,51 or medium criteria. This result showed that blended learning model can be used to increase the critical thinking ability of fifth grade student especially for mathematics subject.
\end{abstract}

Keywords: Blended learning; critical thinking; mathematics.

This is an open access article under the Creative Commons Attribution 4.0 International License

\section{PENDAHULUAN}

Kemampuan berpikir merupakan salah satu hal yang dibutuhkan oleh manusia. Kemampuan berpikir yang dituntut untuk dikuasai di abad 21 saat ini salah satunya adalah kemampuan berpikir kritis ( (Aizikovitsh-Udi \&
Cheng, 2015), (Kalelioglu \& Gulbahar, 2013), dan (Kriel, 2013)). Kemampuan berpikir kritis akan menentukan daya saing seseorang dalam berkompetisi untuk menjadi yang terunggul karena akan meningkatkan daya kompetitif dari individu tersebut. Keterampilan berpikir 
kritis telah diakui sebagai keterampilan yang penting untuk keberhasilan belajar, bekerja dan hidup di abad ke-21 ( (Zare \& Othman, 2015); (Kivunja, 2015), dan (Bermingham, 2015)).

Mengingat pentingnya kemampuan berpikir kritis, maka kemampuan ini perlu untuk dikuasai sejak dini seperti pada peserta didik jenjang sekolah dasar (SD). Salah satu mata pelajaran yang membutuhkan kemampuan berpikir kritis di dalamnya adalah matematika. kemampuan berpikir kritis digunakan dalam memahami dan memecahkan suatu permasalahan dengan mampu menganalisis, mengevaluasi, dan menginterpretasikan pemiki-rannya menjadi lebih baik sehingga terjadinya kesalahan dalam menyelesaikan masalah matematika bisa diminimalisir (Widiantari, Suarjana, \& Kusmariyatni, 2016). Sejauh ini kemampuan berpikir kritis peserta didik SD belum menunjukkan hasil yang cukup memuaskan.

Berdasarkan hasil penelitian sebelumnya, tingkat berpikir kritis peserta didik SD pada mata pelajaran matematika sebesar 42,2\% (Azizah, Sulianto, \& Cintang, 2018). Hasil ini masih tergolong rendah karena masih. Rendahnya kemampuan berpikir kritis peserta didik dapat diakibatkan oleh beberapa faktor, khususnya selama proses pembelajaran berlangsung. Salah satu penyebabnya adalah pendidik belum berhasil melaksanakan pembelajaran yang dapat memfasilitasi peserta didik untuk meningkatkan kemampuan berpikir kritis. Hal ini diperparah dengan adanya pandemi covid-19 sejak maret 2020.

Pandemi covid-19 telah merubah banyak tata cara hidup masyarakat termasuk pula dalam pendidikan. Pendidikan yang semula menerapkan pembelajaran tatap muka harus berubah menjadi pembelajaran jarak jauh (PJJ) atau disebut juga daring. Berdasarkan hasil wawancara dan observasi di SD Negeri 1 Metro Barat, perubahan proses pembelajaran menjadi daring telah memberikan pengaruh yang cukup besar. Salah satunya adalah nilai hasil penilaian tengah semester (PTS) yang cukup rendah yang dimana hasil ini juga menunjukkan rendahnya kemampuan berpikir kritis peserta didik.

Rendahnya kemampuan berpikir kritis peserta didik dan keharusan untuk melaksanakan pembelajaran secara daring, mengharuskan pendidik untuk menerapkan model pembelajaran yang sesuai yang salah satunya adalah model blended learning. Blended learning merupakan kombinasi pembelajaran tradisional dan lingkungan pembelajaran elektronik (Aritonang \& Safitri, 2021). Tujuan utama dari blended learning adalah memberikan kesempatan bagi peserta didik agar dapat belajar mandiri, berkelanjutan, dan berkembang sepanjang hayat, sehingga belajar akan menjadi lebih efektif, lebih efisien, dan lebih menarik (Dwiyogo, 2016).

Penelitian tentang model blended learning serta pengaruhnya terhadap pembelajaran telah cukup banyak dilakukan. Diantaranya mengatakan bahwa model blended learning dapat meningkatkan kemampuan literasi matematis (Aritonang \& Safitri, 2021). Selain itu, model blended learning dapat meningkatkan kemampuan berpikir kritis pada mata pelajaran biologi (Cahyadi, Suciati, \& Probosari, 2012). Lebih lanjut, ada pula penelitian yang menyatakan bahwa model blended learning dapat meningkatkan kemampuan berpikir kritis pada pembelajaran tema ekosistem di kelas V (Hasna, Fajriyah, \& Saputra, 2021). Akan tetapi, berdasarkan penelitian yang sudah pernah dilakukan belum ada 
penelitian tentang pengaruh model blended learning terhadap kemampuan berpikir kritis peserta didik kelas V sekolah dasar pada mata pelajaran matematika.

Berdasarkan uraian di atas, maka perlu dilakukan penelitian tentang pengaruh model pembelajaran blended learning terhadap kemampuan berpikir kritis peserta didik kelas V SD Negeri 1 Metro Barat pada mata pelajaran matematika. Oleh karena itu, tujuan dari penelitian ini adalah untuk melihat ada atau tidaknya pengaruh yang signifikan dari penerapan model pembelajaran pembelajaran blended learning pada mata pelajaran matematika terhadap kemampuan berpikir kritis peserta didik kelas V SD Negeri 1 Metro Barat.

\section{METODE PENELITIAN}

Jenis penelitian yang dilakukan adalah penelitian kuantitatif. Penelitian ini menggunakan jenis metode eksperimen semu (quasi experiment design). Variabel pada penelitian ini yaitu model pembelajaran blended learning $(\mathrm{X})$ dan kemampuan berpikir kritis matematika peserta didik sekolah dasar (Y).

Rancangan desain penelitian yang digunakan adalah non-equivalent control group design. Desain nonequivalen control group design menggunakan 2 kelompok, yaitu kelompok eksperimen dan kelompok kontrol. Kelas eksperimen adalah kelas yang mendapat perlakuan berupa penerapan model pembelajaran blended learning, sedangkan kelas kontrol adalah kelompok pengendali yaitu kelas yang tidak mendapat perlakuan.

Subjek pada penelitian ini adalah peserta didik kelas V SD Negeri 1 Metro Barat. Jumlah populasi sebanyak 36 peserta didik yang terdiri dari kelas VA 20 peserta didik dan kelas VB 16 peserta didik. Teknik pengambilan sampel menggunakan teknik sampel jenuh kemudian dikelompokkan dengan ordinal pairing. Ordinal pairing pada penelitian ini yaitu memasangkan subjek penelitian atau cara pengelompokkan sampel menggunakan sistem peringkat dengan melakukan Tes awal Berpikir Kritis (Taw BK). Tujuan penggunaan ordinal pairing adalah untuk menyamaratakan kemampuan subjek dimasing-masing kelompok. Teknik ordinal pairing dapat dilihat pada Gambar 1.

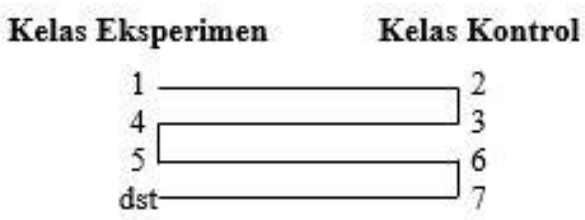

Gambar 1. Teknik Ordinal Pairing

Teknik yang digunakan untuk mengumpulkan keseluruhan data yang berkaitan dengan penelitian ini adalah teknik tes dan nontes. Instrumen tes yang digunakan adalah tes uraian. Teknik nontes yang digunakan adalah observasi. Observasi pada penelitian ini digunakan untuk mengukur aktivitas peserta didik selama proses pembelajaran dengan menggunakan model blended learning. Data yang dianalisis dalam penelitian ini adalah data kuantitatif, yaitu nilai tes akhir berpikir kritis (TaK BK) matematika.

Teknik analisis data pada penelitian ini menggunakan uji statistik inferensial berupa regresi linier sederhana. Adapun hipotesis dari uji regresi yang dilakukan yaitu $\mathrm{H}_{\mathrm{a}}$ (terdapat pengaruh yang signifikan dari penerapan model pembelajara blended learning terhadap kemampuan berpikir kritis matematika peserta didik kelas $\mathrm{V}$ SD Negeri 1 Metro Barat). $\mathrm{H}_{\mathrm{a}}$ diterima jika $F_{\text {hitung }} \geq F_{\text {tabel. }}$. Sebelum melakukan uji regresi perlu dilakukan uji prasyarat 
berupa uji normalitas dan homogenitas. Uji normalitas dilakukan dengan menggunakan rumus Chi Kuadrat dengan kriteria jika $\chi^{2}$ hitung $<\chi_{\text {tabel }}^{2}$ maka populasi berdistribusi normal dan sebaliknya. Sedangkan untuk uji homogenitas menggunakan uji-F dengan kriteria jika $F_{\text {hitung }}<F_{\text {tabel }}$ maka data berasal dari populasi yang homogen homogen dan begitu pula sebaliknya. Selain uji regresi, dihitung pula nilai rata-rata peningkatan kemampuan ( $N$-Gain) sebagai penguat dari uji regresi. Perhitungan nilai $n$-gain dilakukan dengan menggunakan rumus berikut:

$N-$ Gain Score $=\frac{\text { Postest Score }- \text { Pretest Score }}{\text { Maximum Score }- \text { Pretest Score }}$

Setelah diperoleh nilai $n$-gain dan ratarata dari nilai $n$-gain tersebut kemudian diinterpretasikan sesuai dengan Tabel 1.

Tabel 1. Interpretasi dari nilai $N$-Gain

\begin{tabular}{cc}
\hline Nilai N-Gain $(\mathbf{N})$ & Kategori \\
\hline$N>0,7$ & Tinggi \\
$0,3<N \leq 0,7$ & Sedang \\
$N \leq 0,3$ & Rendah \\
\hline
\end{tabular}

(Hartati, 2016)

\section{HASIL DAN PEMBAHASAN}

Data hasil penelitian iperoleh dari nilai TAw BK dan TAk BK pada kelas eksperimen dan kontrol. Deskripsi data penelitian seperti pada Tabel 2.

Tabel 2. Deskripsi data hasil penelitian

\begin{tabular}{|c|c|c|c|c|}
\hline \multirow{2}{*}{ Data } & \multicolumn{2}{|c|}{ Eksperimen } & \multicolumn{2}{|c|}{ Kontrol } \\
\hline & $T A w B K$ & TAk BK & $T A w B K$ & $T A k B K$ \\
\hline $\mathrm{N}$ & 18 & 18 & 18 & 18 \\
\hline $\mathrm{X}(\mathrm{m}$ & 76,5 & 95,6 & 76,5 & 80,9 \\
\hline$X(m$ & 22,1 & 41,2 & 22,1 & 26,5 \\
\hline$\sum$ & 916 & 1288,2 & 23,4 & 1046,8 \\
\hline Mean & 50,89 & 71,57 & 51,30 & 58,16 \\
\hline Medi & 52,9 & 72,05 & 52,9 & 58,85 \\
\hline Moc & 52,$9 ; 60,3$ & 70,$6 ; 89,7$ & 52,9 & 60,3 \\
\hline Deviasi & 13,01 & 15,35 & 13,73 & 13,19 \\
\hline
\end{tabular}

Berdasarkan Tabel 2 diperoleh nilai rata-rata Tak BK kelas eksperimen lebih besar dari pada kelas kontrol. Selain hasil pada Tabel 2, ketika proses pembelajaran di kelas eksperimen dilakukan observasi terhadap aktivitas peserta didik dalam pelaksanaan model pembelajaran blended learning dan menghasilkan nilai model pembelajaran blended learning dengan jumlah ratarata 140,7 .

Setelah diperoleh hasil seperti pada Tabel 2, kemudian dilakukan uji regresi. Akan tetapi, seperti aygn dijelaskan sebelumnya, dilakukan terlebih dahulu uji normalitas dan homogenitas sebagai prasyarat. Hasil uji normalitas dapat dilihat pada Tabel 3.

Tabel 3. Hasil uji normalitas

\begin{tabular}{ccc}
\hline Data & $\mathrm{X}^{2}{ }_{\text {itung }}$ & $\mathrm{X}^{2}$ tabel \\
\hline TAw BK kelas eksperimen & 1,071 & \\
TAw BK kelas kontrol & 0,628 & \\
TAk BK kelas eksperimen & 0,871 & 9,488 \\
TAk BK kelas kontrol & 1,063 & \\
\hline
\end{tabular}

Berdasarkan tabel 3, didapat nilai $\mathrm{X}_{\text {hitung }}^{2}<\mathrm{X}_{\text {tabel }}^{2}$ artinya TAw BK dan TAk BK kelas eksperimen dan kontrol berdistribusi normal. Selanjutnya hasil perhitungan uji homogenitas didapat nilai TAw BK $F_{\text {hitung }}=1,02<\mathrm{F}_{\text {tabel }}=$ 2,29 dan $\mathrm{TAk}$ BK $\mathrm{F}_{\text {hitung }}=1,14<\mathrm{F}_{\text {tabel }}=$ 2,29, maka dapat disimpulkan bahwa data berasal dari populasi yang homogen. Berdasarkan uji prasyarat yang telah dilakukan diperoleh hasil kedua kelas berdistribusi normal dan homogen. Oleh karena itu dapat dilanjutkan uji hipotesis dengan menggunakan uji regresi sederhana.

Persamaan regresi yang diperoleh adalah $\hat{\mathrm{Y}}=7,03+8,28 \mathrm{X}$. Kemudian $F_{\text {hitung }}$ uji signifikansi yaitu 28,37 dengan $\mathrm{n}=18$ untuk taraf kesalahan 5\% diperoleh $F_{\text {tabel }}$ adalah 4,49. Sehingga $\mathrm{F}_{\text {hitung }}>\mathrm{F}_{\text {tabel }}$ yaitu 28,37 $>$ 4,49 maka $\mathrm{H}_{\mathrm{a}}$ diterima artinya terdapat pengaruh 
yang signifikan pada penerapan model pembelajaran blended learning terhadap kemampuan berpikir kritis matematika peserta didik kelas V SD Negeri 1 Metro Barat.

Setelah dilakukan uji regresi, kemudian dilakukan perhitungan nilai $n$-gain dan rata-ratanya. Hasil berupa nilai rata-rata peningkatan kemampuan $(N$-Gain) berpikir kritis matematika yang dapat dilihat pada Tabel 4 .

Tabel 4. Rata-rata $n$-gain

\begin{tabular}{llcc}
\hline No & Kelas & Rata-rata n-gain & Selisih \\
\hline 1 & Eksperimen & 0,51 & \multirow{2}{*}{0,26} \\
2 & Kontrol & 0,25 & \\
\hline
\end{tabular}

Berdasarkan Tabel 4 diperoleh hasil bahwa rata-rata $N$-Gain untuk kelas eksperimen lebih tinggi dibandingkan kelas kontrol. Hal ini menunjukkan bahwa terjadi peningkatan kemampuan berpikir kritis peserta didik dengan penerapan model pembelajaran blended learning lebih signifikan.

Hasil dari penelitian menunjukkan adanya relevansi antara peningkatan kemampuan berpikir sebagai hasil dari penerapan model blended learning di setiap jenjang pendidikan termasuk SD. Model pembelajaran blended learning mampu meningkatkan kemampuan berpikir kritis dan kemampuan pemecahan masalah peserta didik (Suana, Raviany, \& Sesunan, 2019). Pembelajaran dengan model blended learning memberikan pengaruh yang lebih baik terhadap pemahaman konsep dan kelancaran prosedur matematis bagi peserta didik (Nugraha, Astawa, \& Ardana, 2019). Didukung juga oleh pendapat yang menyatakan bahwa model pembelajaran blended learning sangat bermanfaat dikarenakan inovatif, menghasilkan pembelajaran aktif, pembelajaran yang lebih personal, berpusat pada peserta didik dan lebih menarik bagi peserta didik, serta dapat meningkatkan prestasi belajar peserta didik (Sahni, 2019).

Pembelajaran dengan model blended learning memberikan kesempatan peserta didik untuk menjadi pembelajar aktif yang memahami kebutuhan dirinya (Surat, Jayantika, \& Basar, 2021). Pembelajaran dengan model blended learning juga baik untuk meningkatkan efektivitas, efisiensi, dan daya tarik lebih besar bagi peserta didik untuk mengikuti pembelajaran dan memacu untuk berpikir kritis (Abroto, Maemonah, \& Ayu, 2021).

Keuntungan dari pembelajaran blended learning adalah pendidik dapat memanfaatkan kegiatan pembelajaran di dalam dan di luar kelas, memanfaatkan keterampilan untuk menambah pelajaran dan memberikan tema dan pertanyaan secara online dengan cara yang mengatur dan mengendalikannya. Pembelajaran tanpa komunikasi tidak mungkin dilakukan, sehingga pendidik dan peserta didik dapat membentuk (online) di dalam dan luar kelas dengan membentuk kelompok diskusi yang memanfaatkan kemajuan teknologi pada zaman ini (Riinawati, 2021).

\section{KESIMPULAN DAN SARAN}

Berdasarkan hasil dan pembahasan, disimpulkan bahwa terdapat pengaruh yang signifikan pada penerapan model pembelajaran blended learning terhadap kemampuan berpikir kritis matematika peserta didik kelas V SD Negeri 1 Metro Barat.

Saran untuk penelitian selanjutnya adalah untuk dapat menerapkan model pembelajaran yang sesuai dengan tuntutan perkembangan zaman. Model pembelajaran blended learning disarankan dapat dikembangan dalam penerapannya dalam proses pembelajaran abad 21. 


\section{DAFTAR PUSTAKA}

Abroto, A., Maemonah, M., \& Ayu, N. P. (2021). Pengaruh Metode Blended Learning dalam Meningkatkan Motivasi dan Hasil Belajar Siswa Sekolah Dasar. Edukatif: Jurnal Ilmu Pendidikan, 3(5), 1993-2000.

Aizikovitsh-Udi, E., \& Cheng, D. (2015). Developing Critical Thinking Skills from Dispositions to Abilities: Mathematics Education from Early Childhood to High School. Creative Education, 06(04), 455-462.

Aritonang, I., \& Safitri, I. (2021). Pengaruh Blended Learning Terhadap Peningkatan Literasi Matematika Siswa. Jurnal Cendekia: Jurnal Pendidikan Matematika, 05(01), 735-743.

Azizah, M., Sulianto, J., \& Cintang, N. (2018). Analisis Kemampuan Berpikir Kritis Siswa Sekolah Dasar pada Pembelajaran Matematika Kurikulum 2013. Jurnal Penelitian Pendidikan, 35(1): 61-70.

Bermingham, M. (2015). Clearing up "Critical Thinking": Its Four Formidable Features. Creative Education, 6(4), 421-427.

Cahyadi, F. D., Suciati, \& Probosari, R. M. (2012). Penerapan Blended Learning dalam Pembelajaran Biologi untuk Meningkatkan Kemampuan Berpikir Kritis Siswa. Pendidikan Biologi, 4(1), 15-22.

Dwiyogo, W. D. (2016). Pembelajaran Berbasis Blended Learning (Model Rancangan Pembelajaran). Malang: Wineka Media.

Hasna, H. R., Fajriyah, K., \& Saputra, H. J. (2021). The Effect of Blended Learning Based on The
Problem-Based Learning Model Assisted by Puzzle Media on The Critical Thinking Skills of Fifth Grade Students on Ecosystem Themes. Journal of Education Technology, 5(1), 14-22.

Kalelioglu, F., \& Gulbahar, Y. (2013). The Effect Of Instructional Techniques On Critical Thinking And Critical Thinking Dispositions In Online Discussion. Educational Technology and Society, 17(1), 248-258.

Kivunja, C. (2015). Using De Bono's Six Thinking Hats Model to Teach Critical Thinking and Problem Solving Skills Essential for Success in the 21st Century Economy. Creative Education, 6(3), 380-391.

Kriel, C. (2013). Creating A Disposition For Critical Thinking In The Mathematics Classroom. Proceedings of the Second Biennial Conference of the South African Society for Engineering Education , (pp. 67-75). Cape Town.

Nugraha, D. G., Astawa, I. W., \& Ardana, I. M. (2019). Pengaruh Model Pembelajaran Blended Learning terhadap Pemahaman Konsep dan Kelancaran Prosedur Matematis. Jurnal Riset Pendidikan Matematika, 6(1), 7586.

Rahmawati, N. D., Rodliyah, I., \& Saraswati, S. (2021). Pengaruh Model Blended Learning terhadap Kemampuan Berpikir Kreatif pada Mata Kuliah Matematika Diskrit . Seminar Nasional SAINS TEKNOPAK Ke-5 (pp. 1-5). Jombang: LPPM UNHASY TEBUIRENG JOMBANG 2021. 
DOI: https://doi.org/10.24127/ajpm.v10i4.4346

Riinawati. (2021). Hubungan Penggunaan Model Pembelajaran Blended Learning terhadap Hasil Belajar Matematika Siswa Sekolah Dasar. Jurnal Ilmu Pendidikan, 3(6), 3794-3801.

Sahni, J. (2019). Does Blended Learning Enhance Student Engagement? Evidence from Higher Education. Journal of ELearning and Higher Education, 2019, 1-14.

Suana, W., Raviany, M., \& Sesunan, F. (2019). Blended Learning Berbantuan Whatsapp: Pengaruhnya terhadap Kemampuan Berpikir Kritis dan Kemampuan Pemecahan Masalah. Jurnal Ilmiah Penelitian dan Pembelajaran Fisika, 5(2), 37-45.

Surat, I. M., Jayantika, I. T., \& Basar, M. (2021). Pengaruh Model Pembelajaran Blended Learning Terhadap Aktivitas dan Hasil Belajar Matematika Peserta Didik Kelas VII SMP Nasional Denpasar. Jurnal Emasains: Jurnal Edukasi Matematika dan Sains, X(1), 228-237.

Widiantari, N. K., Suarjana, I. M., \& Kusmariyatni, N. (2016). Analisis Kemampuan Berpikir Kritis Siswa Kelas IV dalam Pembelajaran Matematika . e-Journal PGSD Universitas Pendidikan Ganesha Jurusan PGSD, 4(1), 1-11.

Zare, P., \& Othman, M. (2015). Students Perceptions toward Using Classroom Debate to Develop Critical Thinking and Oral Communication Ability. Asian Social Science, 11 (9), 158170. 